\title{
Joko Widodo's Speech after the Constitutional Court Decision; Representation of Ideology and Power
}

\author{
Taqyuddin Bakri*, Mohammad Tahir, Arum Pujiningtyas \\ Department of Language and Art Education, Faculty of Education and Teacher Training \\ Corresponding Author* \\ DOI: https://dx.doi.org/10.47772/IJRISS.2021.5339
}

\begin{abstract}
This article is the result of research conducted on a speech delivered by Joko Widodo. This is in line with the problem in the research, namely how is the representation of ideology and power in Joko Widodo's speech after the Constitutional Court decision? Joko Widodo as the elected president delivered his political speech after the Constitutional Court decided the results of the 2019-2024 Presidential and VicePresidential Election of the Republic of Indonesia. In this decision, the Constitutional Court confirmed that it would reject the lawsuit and decided JokoWidodo and Ma'ruf Amin as the elected President and Vice President of the Republic of Indonesia. In this sense, political speech cannot be viewed as independent. Therefore, Joko Widodo's speech was analyzed using the Huckin model's Critical Discourse Analysis approach. The analysis was carried out using a qualitative descriptive research method. The data source in this study was Joko Widodo's speech after the Constitutional Court decision which was broadcast nationally by the mass media. The analysis was carried out to see the genre, framing, foregrounding or backgrounding, presuppositions, and differences in topics, as well as analysis of sentences and words in Joko Widodo's political speech. The findings obtained, Joko Widodo used straightforward and explicit language and was conveyed in an argumentative and persuasive manner. This delivery uses language and power relations so that the ideology conveyed can be positively accepted by the Indonesian people. and analysis of sentences and words in Joko Widodo's political speeches. The findings obtained, Joko Widodo used straightforward and explicit language and was conveyed in an argumentative and persuasive manner. This delivery uses language and power relations so that the ideology conveyed can be positively accepted by the Indonesian people.
\end{abstract}

Key words: ideology; power; critical discourse analysis; Huckin's Theory

\section{INTRODUCTION}

$\mathrm{T}$ he results of the Presidential and Vice-Presidential Election of the Republic of Indonesia were officially read out by the Judges of the Constitutional Court (MK) on Thursday, 27 June 2019. The reading of the election results constitutionally marked the end of the presidential and vice presidential elections. This is because according to the mandate of the law, the Constitutional Court is a state institution that has the right to decide disputes over political contestation events, one of which is the presidential and vice presidential elections(Okezone 2019; Article 24C of the 1945 Constitution, $\mathrm{tt}$ ).
In the decision read out, the Constitutional Court determined that the pair JokoWidodo and Ma'ruf Amin won the most votes and rejected the entire PrabowoSubianto-Sandiaga S. Uno team. The highest number of votes won JokoWidodo and Ma'ruf Amin who in the contestation number 01 were declared winners, and henceforth they can be immediately determined by the General Election Commission (KPU) of the Republic of Indonesia as President and Vice President for the 2019-2024 period. The reading of the decision also marked the constitutional efforts achieved by the pair PrabowoSubianto and Sandiaga S. Not being rejected by the Constitutional Court. The existence of this rejection provides legal certainty to the public that Indonesia already has an elected President and Vice President. Legal certainty is important, one of which is that the political intensity in the "rising" society can be reduced so that it is hoped that the community can reunite after the long process of holding presidential and vice presidential elections.In this regard, after the Constitutional Court's decision was read, Joko Widodo as a Presidential Candidate who was determined as the winner immediately delivered his political speech(Detikcom 2019). Speech as part of the communication process in language interactions has a specific purpose(Luhukay 2007; Nur 2017). Likewise, the political speech delivered by Joko Widodo.Hidayat (2014) and Nur (2017)argued, speech is a means of oral interaction to convey ideas, ideas, and opinions to the public. As a means of interaction, speeches are also formal in nature and are delivered by people who have positions or powers to achieve certain goals(Nur 2017).

The achievement of the goal in making a speech is intended so that the audience as listeners or speech partners can listen to and accept the intentions of the person giving the speech. Whether it's hidden intentions, or those that mean something straightforward(Asmara 2016; Obojska 2018). In giving a speech too, the speaker emphasized the ideology and power that exists within himself or his group(Bakri dan Pujiningtyas 2017; Eriyanto 2011; Kang 2018). This is intended so that the audience can understand, accept, and carry out the narrative of the speech delivered. Likewise with the speech delivered by Joko Widodo. The victory speech as elected president was delivered in front of his supporters, and was broadcast and reported nationally by the mass media(Detikcom 2019; Kompas 2019). The speeches delivered by Joko Widodo cannot be seen as a mere victory speech, but there is a hidden purpose behind the statements(Bakri dan Pujiningtyas 2017; 
Listo 2018; Sobur 2012). To reveal the meaning of each statement in the speech, the ideology of language used by Joko Widodo was analyzed using the Thomas Huckin model of Critical Discourse Analysis (CDA) approach(Huckin 1997; Nur 2017).

The AWK approach is used because speech in speech does not stand alone, but there are things that underlie it. The things that underlie it can be in the form of election of diction, ideology, and power. To reveal this, the AWK approach is very appropriate to use. This is because AWK does not only analyze language structurally, but functionally and critically(Listo 2018; Pujiningtyas and Bakri 2018). In AWK, there are several analysis models. Therefore, in this study the Huckin analysis model was chosen to reveal the language, framing, ideology, and power used by Joko Widodo.

\section{METHOD}

Qualitative descriptive method is used as a method in this research. This method has a problem-solving procedure by describing the object of research based on data and facts(Moleong 2007). By using this method, the ideology of language used by Joko Widodo is reviewed based on data and underlying facts. The data source in this study is a transcript of Joko Widodo's speech as the elected president after reading the verdict at the Constitutional Court. The data analyzed were words and sentences in the speech statement.

The data collection technique used was the observation technique (Mahsun 2007). In listening, written data is read over and over again, and marked when data is found in accordance with the research topic. Furthermore, the data were analyzed using data reduction techniques(Emzir 2012; Moleong 2007).

In data analysis, the Huckin model AWK approach was used. Huckin in analyzing discourse emphasized that discourse must be understood in main stages, namely: (1) the text as a whole, (2) reading the text in detail, and (3) finding words and phrases and coherence in the text(Gurning 2016; Huckin 1997; Wardani and Laila 2018). The three main stages are used to interpret the use of language and ideology in a discourse text.

\section{DISCUSSION}

\section{Genre}

In his speech after the Constitutional Court decision, Joko Widodo combined the argumentative and narrative genres. At the beginning of his speech, Joko Widodo argued in an argumentative manner of conveying data and facts related to the holding of the ongoing elections. Following is Joko Widodo's affirmation in his speech,

We have gone through all the stages in an open, transparent and constitutional.... (P2-K1)

Joko Widodo with arguments gave confirmation regarding the stages of the Presidential Election. In accordance with the speech delivered, Joko Widodo stated that the stages of the Presidential Election had been carried out in a transparent and constitutional manner. The meaning of "transparent" is real, clear, and does not only involve certain people. This means that the stages of the Presidential Election involve all parties, including the organizers, organizer supervisors, independent institutions, security forces, political parties, and presidential and vice presidential candidates.

The meaning of "constitutional" is the existence of formal rules. Joko Widodo emphasized that the Presidential Election, apart from being implemented in a transparent manner, was also carried out constitutionally. This means that the stages of the Presidential Election are carried out in accordance with applicable legal regulations. The stages that are carried out constitutionally also mean that there is no single stage that violates the rules so that the result of the contestation is valid.

Joko Widodo also conveyed a message to the public that the stages of the Presidential Election had been completed, and the Constitutional Court's decision could no longer be contested. This can be seen from the following speech,

The Constitutional Court's decision is final and we should all respect and implement it.... (P3-K1)

This fragment of Joko Widodo's statement is in accordance with the rules which emphasize that the Constitutional Court is the only institution that has the right to decide disputes over the results of the Presidential Election. Therefore, with the facts, in addition to being argumentative, Joko Widodo also invited all political elites and society to respect and implement the decisions of the Constitutional Court (P3-K1). The persuasive genre statement was also conveyed by Joko Widodo in the statements in his speech. Here's a piece of a persuasive statement,

I invite all Indonesian people to unite again, together to build Indonesia, together to advance the country of Indonesia, our beloved homeland. (P5-K1)

The statement is of a persuasive genre. In his speech, Joko Widodo, apart from affirming data and facts related to the stages of the Presidential Election, also invited all Indonesian people to return to knit unity and jointly build Indonesia. This statement also means that work to advance Indonesia is a collective work, the work of all Indonesian people, without discriminating political choices and other differences.

\section{Framing}

Framing is the framing of an event to form a reader's perspective. Meanwhile, Joko Widodo formed a framing to convince the Indonesian people through his political speech. The framing formed by Joko Widodo to emphasize that the Presidential Election and Election must be a process of maturing the entire political elite and the Indonesian people. Joko Widodo convinced the Indonesian people to respect the Constitutional Court decision, and invited all people to jointly 
develop Indonesia. The framing formed by Joko Widodo can be read in the following speech,

... build a victorious Indonesia in the face of intense global competition, and build a superior situation that brings prosperity to all Indonesians. (P7)

\section{Foregrounding or Backgrounding}

In a discourse text, the speaker or writer can use foregrounding or explicit diction and / or backgrounding or implicit. Likewise with Joko Widodo in his political speech. In this regard, Joko Widodo delivered his political speech to the Indonesian people with explicit diction. The use of explicit diction is expected so that the Indonesian people can immediately understand the message of the statements made by Joko Widodo as the elected president. According to the analysis carried out, there are four explicit statements in the form of affirmations in Joko Widodo's political speech, namely:

1. The people have decided and have been confirmed by the constitution in the way of a civilized and cultured nation. (P1-K4)

2. The Constitutional Court's decision is final and we should all respect and implement it (P3-K1)

3. Even though the political choices are different, we must respect each other. Even though the political choices are different, we must respect each other. (P6$K 1, K 2)$

4. Me and Ma'ruf Amin promised to become president and vice president for the Indonesian people without exception. (P11)

\section{Presupposition}

Joko Widodo's political speech was preceded by a statement regarding the Constitutional Court's decision, an invitation to all the people to respect the Constitutional Court's decision, and an affirmation that the Presidential Election had been implemented in a transparent and constitutional manner. Furthermore, Joko Widodo called on and urged all the people to unite again, put aside the differences that emerged in the presidential election contestations, and invited him to jointly develop Indonesia.

In this regard, the presumption that has emerged is that there are still groups that have not accepted the Constitutional Court decision, and even consider fraud in the Presidential Election. In handling the invitation for unity, the presumption that arises is that it is a problem that can disrupt the unity of the nation. Intertextually, Joko Widodo's statement emerged because the stages of the Presidential Election, even before the stage began, many divisions emerged, even the issue of racial and religious beliefs in the community. Therefore, the Indonesian people, who are very heterogeneous in various aspects, must unite again without looking at the barriers of difference that had emerged.

\section{Different Topics}

The main focus in Joko Widodo's speech was an invitation to respect the Constitutional Court decision and strengthen national unity. The speech can be said to be different from the social reality that happened. Before the stages, during the stages, until the Presidential Election is over, divisions of differences emerge in society that can threaten the unity of the nation. The issue of SARA, to the arena of mutual slander that developed and was disseminated massively on social media became a social reality that adorned the presidential election contestation event. Not only the dissemination of information that brought down JokoWidodo-Ma'ruf Amin, but also the dissemination of information demeaning the PrabowoSubianto-Sandiaga S. Uno pair.

This fact is a fact that there is a potential for lack of national unity. The lack of national unity has implications for the harmony of the people. Between the people or one group with another group can be separated in terms of differences. Whereas in the concept of "Unity in Diversity", differences are interpreted as treasures to unite the nation. Therefore, in his political speech, Joko Widodo continued to emphasize the Indonesian people to respect the Constitutional Court's decision and call for strengthening national unity.

Analysis of Sentence and Word Levels

\section{Topicalization}

Joko Widodo's speech explicitly presented topics related to an invitation to the Indonesian people to accept the Constitutional Court decision and jointly develop Indonesia. Joko Widodo always emphasizes his statements by using the word "we". "We" is an exclusive pronoun which denotes the presence of a speaker and an audience at one time or another. This means, Joko Widodo emphasized that all stages of the Presidential Election have been passed together so that they must be accepted together as well. Joko Widodo also used the word "we" to invite the Indonesian people to jointly develop Indonesia. Here are some statements that use the exclusive pronouns,

1. The election process for the presidential and legislative elections that we have gone through in 10 months....

2. We have gone through the campaign registration stages, then voting, vote counting, determination of recapitulation results by the KPU, supervision by Bawaslu, and dispute resolution in the Supreme Court and the Constitutional Court.

3. We have gone through all the stages in an open, transparent and constitutional manner....

4. The Constitutional Court's decision is final and we should all respect and implement it....

5. Even though the political choices are different, we must respect each other. Even though the political choices are different, we must respect each other.

6. I'm sure our passion is the same.... 


\section{Ideational}

In his ideational function, Joko Widodo as the speaker emphasized his role as an agency or figure who played a role in the speech. Joko Widodo through his statement emphasized to all Indonesian people that he was the winner of the presidential election contest. As the winner and later inaugurated as President of the Republic of Indonesia, Joko Widodo has the responsibility to unite this nation.

\section{Insinuation}

Insinuation is a part of utterances or comments that are implied or suggestive. The following is the insinuation delivered by Joko Widodo,

Even though the political choices are different, we must respect each other. Even though the political choices are different, we must respect each other. Even though the political choices were different during the presidential election, we say that the elected president and vice president are the president and vice president for all of the nation's children for all Indonesian people.

Joko Widodo realized that the presidential election still left a barrier of differences. Both differences between political parties and differences of opinion among the Indonesian people. The existence of differences that could threaten the spirit of unity made Joko Widodo feel the need to convey that there are indeed differences in political choices, but the spirit and attitude of mutual respect and respect must be upheld. This is in accordance with the philosophy of "Bhineka Tunggal Ika" so that at the end of the sentence, Joko Widodo explained that the elected president and vice president are the president and vice president for all Indonesian people, not the president and vice president for those who elect only.

\section{Language and Ideological Representations}

Language is a means of conveying messages to other people or speech partners. The message conveyed is the desire or ideology of the speaker or speaker. Through language, the speaker wants to express his ideology in order to be understood and followed by other people or speech partners(Bakri dan Pujiningtyas 2017; Lo Bianco 2020). In his political speech, Joko Widodo used straightforward and explicit language. This was done so that other people, in this case the Indonesian people, could understand the message in his political speech. The ideology shared by Joko Widodo in the speech he delivered was his desire for the Indonesian people to accept the Constitutional Court's decision and together unite to build Indonesia. The ideology is conveyed in an argumentative and persuasive manner.In his political speech, Joko Widodo used straightforward and explicit language. This was done so that other people, in this case the Indonesian people, could understand the message in his political speech. The ideology shared by Joko Widodo in the speech he delivered was his desire for the Indonesian people to accept the Constitutional Court's decision and together unite to build Indonesia. The ideology is conveyed in an argumentative and persuasive manner.

Argumentatively, Joko Widodo explained the data and facts related to the stages that had been carried out in a transparent and constitutional manner, as well as the results of the Presidential Election which had been decided by the Constitutional Court. Through conveying his ideology, Joko Widodo sent a message to the political elite and the Indonesian people, that he was the elected President of the Republic of Indonesia who had gone through the constitutional route. Therefore, Joko Widodo persuasively invites all elements of the Indonesian people not to dissolve in the barriers of difference, and still uphold mutual respect and respect as the Indonesian nation. This is so that JokoWidodo and Ma'ruf Amin as President and Vice President of the Republic of Indonesia for the 2019-2024 period can work together with all elements of the political elite and the Indonesian people in developing and advancing Indonesia. The use of language to show ideology can be seen as positive and negative. However, in Joko Widodo's speech, the ideology conveyed was positive.

\section{CONCLUSION}

Joko Widodo shows strength and power through language as the conveyor of his ideology. Joko Widodo's use of straightforward and explicit language in his speech was influenced by the power that Joko Widodo had as the elected president. In a speech according to the results of genre analysis, framing, foregrounding, presuppositions, and differences in topics, as well as sentence and word analysis, Joko Widodo tries to influence the Indonesian people to understand and follow the message or ideology conveyed. This is in line with AWK Huckin's theory, so it can be concluded that Joko Widodo realizes the correlation between language and power as the most appropriate means of conveying ideology in influencing the Indonesian people.

\section{REFERENCE}

[1] Asmara, Rangga. 2016. "STRATEGI KEBAHASAAN PRESIDEN JOKOWI DALAM MENANAMKAN IDEOLOGI DAN MANIFESTO PEMERINTAHAN.” LITERA 15 (2): 37988. https://doi.org/10.21831/ltr.v15i2.11836.

[2] Bakri, Taqyuddin, dan Arum Pujiningtyas. 2017. "REPRESENTASI IDEOLOGI DALAM HEADLINE PEMBERITAAN HARIAN RADAR SULTENG." Dalam Prosiding Seminar Tahunan Linguistik Universitas Pendidikan Indonesia (SETALI 2017), 460-70. Universitas Pendidikan Indonesia, Bandung: Program Studi Linguistik, Sekolah Pascasarjana UPI.

[3] Detikcom. 2019. "MK Tolak Gugatan Pilpres Prabowo-Sandiaga." news.detik.com, 27 Juni 2019. https://news.detik.com/berita/d4603147/mk-tolak-gugatan-pilpres-prabowo-sandiaga.

[4] Emzir. 2012. Metodologi Penelitian Kualitatif: Analisis Data. Jakarta: Rajawali Press.

[5] Eriyanto, Eriyanto. 2011. Analisis Wacana: Pengantar Analisis Teks Media. Yogyakarta: LKiS.

[6] Gurning, Busmin. 2016. "Analisis Wacana Kritis: Analisis Bahasa Berdasarkan Fungsi Sosial.” Jurnal Bahasa FBS Unimed. http://digilib.unimed.ac.id/id/eprint/248.

[7] Hidayat, Hadi. 2014. "PEMANFAATAN FITUR METAFORA DALAM TEKS PIDATO POLITIK SHINZO ABE SEBAGAI 
PERDANA MENTERI JEPANG KE-96: ANALISIS WACANA KRITIS." Metalingua $\quad 12$ http://dx.doi.org/10.26499/metalingua.v12i2.24.

[8] Huckin, T. 1997. Critical Discourse Analysis. In T. Miller (Ed.) Functional Approaches to Written Text: Classroom Applications. Washinton DC: United States Information Agency.

[9] Kang, Kyong Deock. 2018. "Language and Ideology: Althusser's Theory of Ideology." Language Sciences 70 (November): 68-81. https://doi.org/10.1016/j.langsci.2018.06.008.

[10] Kompas. 2019. "MK Tolak Seluruh Gugatan Prabowo-Sandiaga," 27 Juni

2019 https://nasional.kompas.com/read/2019/06/27/21163631/mk-tolakseluruh-gugatan-prabowo-sandiaga?page=all.

[11] Listo, Romy. 2018. "Gender Myths in Energy Poverty Literature: A Critical Discourse Analysis." Energy Research \& Social Science 38 (April): 9-18. https://doi.org/10.1016/j.erss.2018.01.010.

[12] Lo Bianco, Joseph. 2020. "Ideologies of Sign Language and Their Repercussions in Language Policy Determinations." Language \& Communication $\quad 75 \quad$ (November): https://doi.org/10.1016/j.langcom.2020.09.002.

[13] Luhukay, Marsefio S. 2007. "PRESIDEN SBY DAN POLITIK PENCITRAAN: Analisis Teks Pidato Presiden SBY Dengan Pendekatan Retorika Aristoteles.” Jurnal Ilmiah Scriptura 1 (2). https://doi.org/10.9744/scriptura.1.2.

[14] Mahsun, M. S. 2007. Metode Penelitian Bahasa: Tahapan Strategi, Metode, dan Tekniknya. Jakarta: PT. Raja Grafindo Perkasa.

[15] Moleong, Lexy J. 2007. Metodologi Penelitian Kualitatif. Bandung: PT. Remaja Rosdakarya.

[16] Nur, Adam Muhammad. 2017. "BAHASA, IDEOLOGI DAN POWER PADA PIDATO KEMENANGAN GUBERNUR DKI
JAKARTA TERPILIH ANIES BASWEDAN: PENDEKATAN ANALISIS WACANA KRITIS." Dalam Prosiding Seminar Tahunan Linguistik Universitas Pendidikan Indonesia (SETALI 2017), 16-21. Universitas Pendidikan Indonesia, Bandung: Program Studi Linguistik, Sekolah Pascasarjana UPI.

[17] Obojska, Maria. 2018. "Between Duty and Neglect: Language Ideologies and Stancetaking among Polish Adolescents in Norway." Lingua 208 (Juni): 82-97. https://doi.org/10.1016/j.lingua.2018.03.009.

[18] Okezone. 2019. "Yusril Bilang Wewenang MK Hanya Putuskan Sengketa Hasil Pilpres 2019." news.okezone.com, 18 Juni 2019. https://news.okezone.com/read/2019/06/18/605/2067835/yusrilbilang-wewenang-mk-hanya-putuskan-sengketa-hasil-pilpres2019.

[19] Pasal 24C UUD 1945. t.t. Pasal 24C UUD 1945.

[20] Pujiningtyas, Arum, dan Taqyuddin Bakri. 2018. "KEKERASAN SIMBOLIK DALAM PEMBERITAAN TAMBANG EMAS POBOYO PADA MEDIA MASSA DI KOTA PALU." Dalam Prosiding Seminar Tahunan Linguistik Universitas Pendidikan Indonesia (SETALI 2017). Universitas Pendidikan Indonesia, Bandung: Program Studi Linguistik, Sekolah Pascasarjana UPI.

[21] Sobur, Alex. 2012. Analisis Teks Media: Suatu Pengantar untuk Analisis Wacana, Analisis Semiotik, dan Analisis Framing. Bandung: Rosdakarya.

[22] Wardani, Ifah, dan Malikatul Laila. 2018. "Power And Ideology Of Ashin Wirathu's Speeches Toward Muslim In Rohingya: Critical Discourse Analysis." Universitas Muhammadiyah Surakarta. 


\section{ATTACHMENT}

Joko Widodo's speech

Assalamualaikumwr. wb.

Good night

Best wishes

Ladies and gentlemen, and my fellow countrymen, all the Indonesian people whom I love. The election process for the presidential and legislative elections that we have gone through in 10 months has become a lesson for maturity in our democracy in our country. The people have spoken, they wish, the voice of the people has been heard. The people have decided and have been confirmed by the constitution in the way of a civilized and cultured nation. We have gone through the campaign registration stages, then voting, vote counting, determination of recapitulation results by the KPU, supervision by Bawaslu, and dispute resolution in the Supreme Court and the Constitutional Court.

We have gone through all the stages in an open, transparent and constitutional manner and thank God that tonight we both know the outcome of the Constitutional Court decision. We witnessed the trial process at the Constitutional Court which was carried out fairly and openly and witnessed directly by all Indonesian people through television and other electronic media.

The Constitutional Court decision is final and we should all respect and implement it together. The success of the Indonesian nation in holding honest and fair elections is something we should be grateful for.

Thank you to the KPU, to Bawaslu, and to DKPP, who through their respective roles have succeeded in ensuring the implementation of an honest and fair election. Thank you to law enforcers, including the Supreme Court and the judiciary under it, who have overseen the fair election law enforcement process. We also thank the TNI and Polri for securing the election. And our gratitude goes to the Constitutional Court for deciding the dispute over the presidential election fairly and transparently.

I invite all Indonesian people to unite again, together to build Indonesia, together to advance the country of Indonesia, our beloved homeland. There are no more 01 and 02, only the unity of Indonesia.

Even though the political choices are different, we must respect each other. Even though the political choices are different, we must respect each other. Even though the political choices were different during the presidential election, we say that the elected president and vice president are the president and vice president for all of the nation's children for all Indonesian people.

I am sure that our spirit is the same, namely Indonesia which is united to build a developed Indonesia, which is able to stand side by side with other big countries, build an Indonesia that wins in the face of intense global competition, and builds a superior situation that brings prosperity to all people. I believe in the generosity and statesmanship of my good friends, Mr. PrabowoSubianto and Mr. Sandiaga Uno. He both have the same vision in developing Indonesia in the future. A better Indonesia, a more advanced, just, prosperous Indonesia.

Once again I thank all Indonesian people. Hopefully, we can carry out the mandate returned to me as president and Ma'ruf Amin as vice president for the 2019-2024 period. To achieve a just development, equitable development for the sake of all social justice for the people of Indonesia.

Our gratitude also goes to all coalition parties, all volunteers who have worked hard. And once again for all Indonesian people. Me and Ma'ruf Amin promised to become president and vice president for the Indonesian people without exception. 